\title{
ATHLETE BRANDING IN LESS POPULAR SPORT: A TRIADIC APPROACH
}

\author{
Ali Hasaan (Ph. D.) \\ Assistant Professor, Institute of Research and \\ Advances Studies (IRAS) \\ Faculty of Economics \& Management \\ Opp. BZU Metro Station, Bosan Road \\ Multan, Pakistan \\ ali_hasaan@hotmail.com \\ Vajiheh Javani (Ph.D) \\ Assistant Professor, Department of Sport \\ Management \\ Faculty of Physical Education \& Sport Sciences \\ University of Tabriz ,Tabriz, Iran \\ v.javani@tabrizu.ac.ir \\ Mücahit Fișne(Ph.D.) \\ Assistant Professor \\ Sivas Cumhuriyet University \\ Sports Sciences Faculty, 58140 \\ Sivas, Turkey. \\ mfisne@cumhuriyet.edu.tr \\ Shintaro Sato (Ph.D.) \\ Associate Professor \\ Faculty of Sport Sciences \\ Waseda University, Japan. \\ Faculty of Sport Sciences \\ Waseda University \\ Japão \\ satoshintaro@aoni.waseda.jp
}

Abstract

Objective of the study: Despite the opportunities to develop athlete brands, many athletes in less popular sport still struggle with developing their brands. Therefore, the current study aimed to contribute to the existing athlete branding literature and practitioners by providing a better and holistic understanding of athlete branding in less popular sport.

Methodology: The current we employed a triadic approach that was involved with three stakeholders: Athlete, fans, and media to explore important factors in athlete branding strategies in less popular sport.

Originality/ Relevance: There is less focus on less popular sport and their stakeholders branding. With increasing interest from fans less popular sport and their athletes are gaining more attention than ever. Thus, the study opted to discuss an ignored phenomenon in the context of athlete branding.

Main results: The result of the study identified four main themes and eight associated subthemes based on both the interview and media content analysis. These main and subthemes include (1) performance (on-field success, competition level), (2) personal/private (off-field characteristics, impression management), (3) business/marketing (athlete promotion, merchandized products), and (4) contextual factor (sport nature, proximity).

Theoretical / methodological contributions current study contributed in the existing literature of athlete branding via focusing a top athlete of less popular sport.

Keywords: Athlete. Athlete branding. Sport marketing. Wrestling. Taha Akgül. 
Cite como

American Psychological Association (APA)

Hasaan, A., Javani, V., Fisner, M., \& Sato, S. (2020, set./dez.). Athlete branding in less popular sport: a triadic approach. PODIUM Sport, Leisure and Tourism Review, São Paulo, 9(Edição Especial), 70-96. https://doi.org/10.5585/podium.v9i4.17580.

\section{BRANDING (MARCA) DE ATLETA EM ESPORTE MENOS POPULAR: UMA ABORDAGEM TRIÁDICA}

\section{Resumo}

Objetivo do estudo: Apesar da existência de oportunidades de desenvolvimento de marcas dos atletas, em esportes menos populares os atletas encontram dificuldades neste tema. Portanto, o presente estudo teve como objetivo contribuir com a literatura existente sobre a marca do atleta, fornecendo uma compreensão melhor e holística da marca do atleta em esportes menos populares.

Metodologia: Empregamos a abordagem triádica que envolveu três partes interessadas: Atleta, fãs e mídia, para explorar fatores importantes nas estratégias de marca do atleta em esportes menos populares..

Originalidade/Relevância: Há menos foco no esporte menos popular e na marca de seus stakeholders. Com o crescente interesse dos fãs por esportes menos populares e seus atletas estão ganhando mais atenção do que nunca. Assim, o estudo optou por discutir um fenômeno ignorado no contexto da marca do atleta.

Principais resultados: Os resultados identificaram quatro temas principais e oito subtemas associados com base nas entrevistas e na análise de conteúdo da mídia. Esses principais e subtemas incluem (1) desempenho (sucesso esportivo, nível de competição), (2) pessoal / privado (características fora do esporte, gerenciamento de imagem), (3) negócios / marketing (promoção de atleta, produtos mercadológicos) e (4) fator contextual (natureza esportiva, proximidade).

Contribuições teóricas/metodológicas: o estudo atual contribuiu na literatura existente sobre a marca do atleta por meio do foco em um atleta importante de um esporte menos popular.

Palavras-chave: Atleta . Marca do atleta. Marketing esportivo. Luta Olímpica. Taha Akgül.

\section{MARCA DE ATLETA EN UN DEPORTE MENOS POPULAR: UN ENFOQUE TRIADICO}

\section{Resumén}

Objetivo del estudio: A pesar de la existencia de oportunidades para desarrollar marcas de deportistas, en deportes menos populares, los deportistas encuentran dificultades en este tema. Por lo tanto, el presente estudio tuvo como objetivo contribuir a la literatura existente sobre la marca del deportista, proporcionando una comprensión mejor y holística de la marca del deportista en los deportes menos populares.. 
Metodología: Empleamos lo enfoque triádico que involucró a tres partes interesadas: atleta, fans y medios de comunicación para explorar factores importantes en las estrategias de marca de atleta en deportes menos populares.

Originalidad/Relevancia: Hay menos enfoque en los deportes menos populares y la marca de sus partes interesadas. Con el creciente interés de los fanáticos del deporte menos popular y sus atletas, están ganando más atención que nunca. Por lo tanto, el estudio optó por discutir un fenómeno ignorado en el contexto de la marca de los atletas.

Resultados principales: Los resultados identificaron cuatro temas principales y ocho subtemas asociados basados en entrevistas y análisis de contenido de los medios. Estos temas principales y subtemas incluyen (1) rendimiento (éxito deportivo, nivel de competencia), (2) personal / privado (características no deportivas, gestión de imagen), (3) negocios / marketing (promoción de atletas, productos de marketing) y (4) factor contextual (carácter deportivo, proximidad).

Contribuciones teóricas / metodológicas: El estudio actual contribuyó a la literatura existente sobre la marca de atletas al enfocarse en un atleta de élite de un deporte menos popular.

Palabras clave: Atleta. Marca de atleta. Marketing desportivo. Lucha. Taha Akgül.

Various stakeholders (e.g., athletes, teams, clubs, countries, events) have been able to enjoy a fruitful return on investments in the sport business thanks to the wide variety of sport business opportunities (Dickson \& Santos, 2016). Consumers can easily view the performance of athletes and gain greater insight into sport athletes' characteristics off-the-field because of the established media coverage that can reach the audience worldwide. This phenomenon has not only helped top athletes in popular sport such as Cristiano Ronaldo (football), Roger Federer (tennis), and LeBron James (basketball), but also provided the opportunities for athletes in the relatively less popular sport. For instance, Ronda Rousey (Mixed Martial Arts; MMA), Usain Bolt (track and field) and Michael Phelps (swimming) have successfully established their brands by demonstrating the outstanding performances and off the field characters. Rousey is the most followed female athlete on Instagram. Usain Bolt is considered as the seventh most popular athlete worldwide while Michael Phelps is regarded as the world best swimmer in history. Despite the opportunities to develop athlete brands, many athletes in less popular sport still struggle with developing their brands. It is partly because of consumers' lack of awareness and associations with those athletes, making it difficult to establish strong brand equity (Aaker, 1991).

Athlete brands have been regarded as a collection of associations that consumers have with focal athletes (Arai, Ko, \& Kaplanidou, 2013; Arai, Ko, \& Ross, 2014; Hasaan, Kerem, 
Biscaia, \& Agyemang, 2018). Understanding the perspectives from consumers (fans in this case) is, therefore, indispensable in the process of building and utilizing athlete brands. The majority of athlete branding literature has focused on consumers' perceptions and thoughts about athlete brands (Arai et al. 2013; Walsh \& Williams, 2017). Nevertheless, scholars have largely overlooked the relationships among multiple stakeholders (i.e., athletes, fans, and media). Understanding the potential gaps between the athlete, fans, and media in terms of the branding process is essential for athletes in the less popular sport to effectively develop successful athlete branding strategies.

Figure 1 - Triadic relationship among athlete, fan, and media

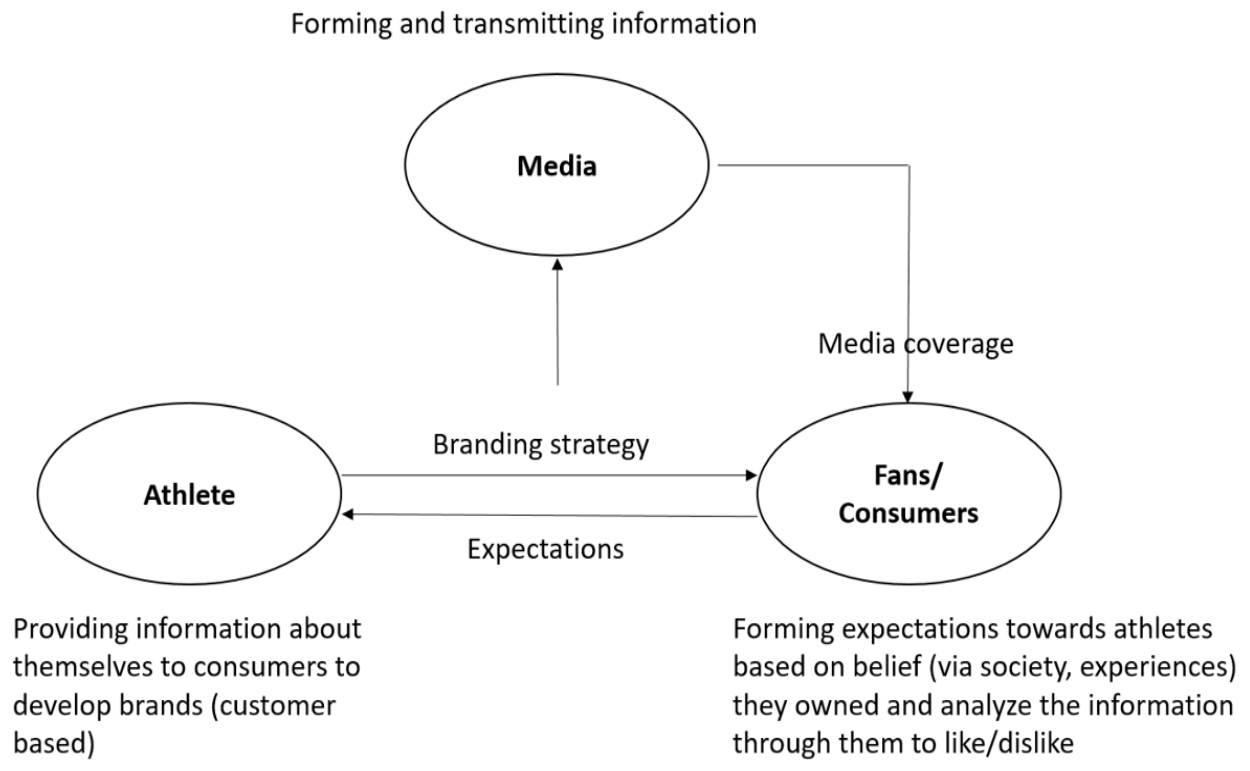

Source: Authors.

The current study contributes to the field of athlete branding. As past studies have ignored to investigate athlete branding using a triadic approach, this study offers a new prospect to examine the athlete branding phenomenon from multiple perspectives. Also, this study discussed the less popular sport athletes in the branding context. Past studies have identified that the types, popularity, and nature of sport demonstrated different effects on brand equity of athletes (Hasaan et al., 2018). In this context, the current study provides a significant contribution to the literature as well as practitioners who manage athlete branding. 
The purpose of the study is two-fold. First, the authors explore similarities and differences in terms of thoughts about athlete branding between athletes and fans. As shown in Figure 1, it will help athletes/managers to implement effective branding strategies that meet fans' expectations. Second, the study also investigates how media attention is allocated based on media content analysis. Since fans' impressions about athletes are strongly influenced by information disseminated by media (Knight \& Giuliano, 2001; Parmentier \& Fischer, 2012), it is crucial to understand what types of media contents about athletes are delivered to fans. For the first purpose, the current study adopted semi-structured interviews with Taha Akgül (Olympic, World, and European Turkish freestyle wrestling champion) and his fans to observe thoughts and opinions of the athlete branding strategies (athlete's perspective) and what expectations fans have (fans' perspective). The selection of the sport deemed appropriate as wrestling is considered a less popular sport (Augestad, Bergsgard, \& Hansen, 2006). For the second purpose, in addition to the perspectives from the athlete and fans, we further incorporate the media perspective based on the content analysis of a Turkish online sport website giant, NTV Spor. In our best knowledge, this is the first athlete branding study focusing on the less popular sport that incorporates the perspectives of multi-stakeholders. The current study aimed to contribute to the existing athlete branding literature and practitioners by providing a better and holistic understanding of athlete branding in less popular sport.

\section{Literature review}

Brand management has served as a tool to cultivate and harness external perceptions, including those of fans, managers, and media. Branding is effective, powerful, and sustainable way to influence consumers in various ways such as increasing recognition/recall and interests (Harris, 2009; Montoya \& Vandehey, 2002; Underwood, 2003), forming positive attitude (Chen, Lin, \& Claussen, 2012; Kim \& Na, 2007), and driving purchase behavior (Fink, Cunningham, \& Kensicki, 2004; Till \& Busler, 2000). Strong brands can also provide marketers with a competitive edge and market performance (Ali-Choudhury, Bennett, \& Savani, 2009; Watkins \& Gonzenbach, 2013). According to Thomson (2006), not only companies or products but also individuals such as athletes can develop their human brands to generate the aforementioned positive outcomes.

Previous literature has supported various positive outcomes generated by athlete branding. Therefore, prominent athletes can attract audience attention widely (Franck \& 
Nüesch, 2012; Jonker, Elferink-Gemser, \& Visscher, 2009; Wylleman \& Reints, 2010). Wellbranded athletes can attain price premiums on their salary, transfer fees, and consistent fan support and loyalty (Arai et al. 2014; Kunkel, Hill, \& Funk, 2013). Well-branded athletes have the potential to attract endorsement offers from companies and can leverage post-athletic career through symbolic value (Rein, Kotler, \& Shields, 2006). Athletes who successfully developed their brands can also be protected from unexpected performance slumps and reputation-harming incidents (Rein et al. 2006; Sato, Ko, Chang, \& Kay, 2019). Stakeholders can also receive potential benefits as star athletes can be a significant factor of consumer behavior towards sport teams (Hodge \& Walker, 2015; Kerr \& Gladden, 2008). As such, previous literature has provided evidence that athlete branding can bring various positive impacts to multiple stakeholders. However, past studies have focused on the outcomes of well-recognized athletes or athletes who compete in the popular sport. The effort in understanding how athletes in less popular sport can develop their human brands and enjoy the fruitful return of investment has particularly been scarce.

\section{The process of athlete branding}

The process of the personal brand begins by promoting athletes' strengths and uniqueness to a target audience (Chen, 2013; Delisle \& Parmentier, 2016). Successful athlete branding is, therefore, understanding the perceptions and expectations of consumers and managing them to satisfy consumers (Montoya \& Vandehey, 2002). However, personal branding faces unique challenges, which mainly rooted in the lack of understanding from the perspectives of multiple stakeholders such as fans and media (Rampersad, 2009). Therefore, it is essential to incorporate multiple perspectives to understand athlete brands. In this study, we particularly focused on the following triadic perspectives: athletes, fans, and media.

First, past studies that mainly incorporated the athlete perspective focused on athletes' perceptions and opinions in terms of brand development strategies. For example, Hodge and Walker (2015) discussed how professional athletes could build value in the market place by focusing on athletes. Cortsen (2013) also conducted a study incorporating the perspective of Annika Sörenstam, a Swedish professional golfer, regarding how she managed her brand image to develop a strong brand. Second, several scholars have tried to explain the branding strategies of professional athletes from the fans' perspective (Arai et al. 2014; Chadwick \& Burton, 2008; 
Parmentier \& Fischer, 2012). Previous literature has developed personal branding models for professional athletes and discussed developing athlete brands. The central tenet that contributes to this line of athlete branding literature is customer-based brand equity, mainly focusing on perceptions that customers have towards the target athletes (Arai et al. 2014; Biscaia, Correia, Ross, Rosado, \& Maroco, 2013; Hasaan et al. 2018; Keller, 1993). Other researchers also argued that awareness and prestige among fans are essential for athletes to be considered as a brand (Arai et al. 2014; Hasaan et al. 2018). Lastly, incorporating the media influence is particularly important to understand athlete branding as consumers are strongly influenced by media (Parmentier \& Fischer, 2012). Also, understanding how media portray athletes in less popular sport can help marketers to develop effective media management strategies. Accordingly, the present study adopted triadic perspectives involving professional athlete, fans, and media to explore important factors in athlete branding strategies in less popular sport. Specifically, the following research questions guided the current investigation:

RQ1: What factors can contribute to athlete branding in less popular sport from athletes and fans' perspectives?

RQ2: Are there any (in)consistencies between what athletes and fans think?

RQ3: What kind of contents about athletes who compete in less popular sport does media cover?

\section{Method}

\section{Research Setting}

The current study employed a triadic approach that was involved with three stakeholders: Athlete, fans, and media. This approach was deemed appropriate for the current research as it is useful when researchers aim to understand complex phenomena by exploring in-depth information from multiple stakeholders (Berg, 2000; Creswell, 2003). The current study centered an athlete, Taha Akgül, to explore effective branding strategies. Taha is a Turkish freestyle wrestler who is an Olympic, World and European Champion competing in the $125 \mathrm{~kg}$ division. He has a long history of achievements, such as two times winner of world 
champion, six times European champion, and an Olympic gold medal at the Rio 2016 (Quliyev, 2018). He was also awarded the title of "best wrestler of the world" in 2014 by United World Wrestling (UWW), the international governing body for the sport of wrestling. After his progress over the years, he is a recognized legend in the history of Turkish sports (Mike, 2013). As a research setting, we focused on opinions in terms of athlete branding provided by Taha and their fans. Also, we conducted media content analysis to understand what kinds of contents about the athlete are covered by media.

\section{Data Collection and Participants}

In the current study, the authors employed two different data collection methods. To collect data from the athlete and fans, a series of semi-structured face-to-face interviews were conducted. Since we focused on branding of athletes, it is deemed appropriate to recruit interview participants who were at least knowledgeable in athletes and sports because a successful sampling enables researchers to access thoughts of the participants (Okumus, Altinay, \& Roper, 2007). In the initial sampling phase, the current study utilized one of the authors' established relationship with various sports stakeholder groups (i.e., sport organizations, athletes, and sport researchers). The authors sent emails to those groups to find potential interview participants based on the following criteria: (1) individuals who had at least basic knowledge and interest in sport, and (2) those who knew Taha Akgül as an athlete at the time of recruitment. In the second sampling phase, the authors employed snowball sampling to recruit further participants who were acquaintances of the participants recruited in the first step (Browne, 2005). We employed an on-going sample size determination (Marshall, 1996); meaning that more participants were recruited until data reached the saturation. As a result, the authors interviewed a total of 11 participants, including Taha. The authors developed an interview guide by the interview guidelines (Patton, 2002; Yin, 2011) to minimize potential inconsistencies between each interview session. Each interview consisted of two sections. The first section included questions focused on athletes in general while the second section focused on Taha Akgül Taha (himself in the case of the interview with him). Participants were asked to provide their opinions about the athlete's branding strategies and how Taha (himself in case of interview with him) is different/similar to other athletes. All interviews lasted between 35 and 45 minutes, depending upon participant interest and willingness to share his/her thoughts. To 
protect the participants' identities, we assigned an identification number for a publication purpose (e.g., F1, F2, F3). Participants' age ranged from 20 to 46 years old.

Table 1 - Participant characteristics

\begin{tabular}{l|l|l|l}
\hline \multicolumn{1}{c|}{ Fan } & \multicolumn{1}{|c|}{ Gender } & \multicolumn{1}{c}{ Age } & \multicolumn{1}{c}{ Profession } \\
\hline F1 & Male & 24 & Self employed \\
\hline F2 & Male & 20 & University Student \\
\hline F3 & Male & 34 & Academician \\
\hline F4 & Male & 29 & PhD Student \\
\hline F5 & Male & 41 & Retired Athlete, Coach (Wrestling) \\
\hline F6 & Male & 40 & Coach (Wrestling) \\
\hline F7 & Female & 26 & University Student \\
\hline F8 & Male & 33 & Sport's Brand Marketing Manager \\
\hline F9 & Male & 46 & Retired Athlete (Wrestling), TV expert \\
\hline F10 & Female & 35 & Sport Blogger, Bank Officer \\
\hline
\end{tabular}

Source: Authors.

The authors also procured media data by conducting content analysis. Content analysis is a useful technique to study a broad range of topics in social research (Macnamara, 2011). The uses of content analysis have been particularly prevalent in media analysis (Newbold, Boyd-Barrett \& Van Den Bulck, 2002). We chose a Turkish online sport website, NTV Spor (www.ntvspor.net). The site was selected as it was among the most popular sports websites in Turkey. All news articles related to Taha Akgül that published during March 2012 to August 2018 was searched using the combinations of the following keywords, "Taha," "Taha Akgul," "Taha Akgül," and "wrestling." This search process resulted in 69 articles found for analysis. It is indeed surprising that the number of articles is small, but it could be common for relatively less known athletes who compete in the less popular sport.

\section{Data analysis}

The interview data analysis was commenced after the first interview, as this strategy allows the researchers to become more familiar with the participants' responses (Marshall \& Rossman, 1995). The authors adopted two-level coding system (i.e., the open coding level and the axial level). Open coding (i.e., breaking data apart and delineating concepts to stand for blocks of raw data; Corbin \& Strauss, 2008) was employed for the initial analysis to generate the themes. The researchers then employed axial coding (i.e., the process of crosscutting or 
relating the initial themes to one another to classify them into more specific themes; Corbin \& Strauss, 2008). After the lead author summarized the data, the results were discussed with the other researchers to confirm the findings (McTavish \& Loether, 2015). To achieve inter-coder reliability, the researchers adopted Campbell, Quincy, Osserman, and Pedersen's (2013) instructions. The first author of the study served as a principal investigator (PI). Once interviews were transcribed, PI identified units of analysis. This version was shared with the second author, and both authors assign codes and develop themes. Then, the authors compared their coded transcripts to see whether there were discrepancies in the coding. The final inter-coder reliability measured via Cohen's Kappa was .91. After that, the remaining discrepancies and disagreements were discussed until reaching the agreement.

Regarding the media content analysis, the conventional approach was used in the study as this approach is useful when researchers aim to describe a complex phenomenon (Hsieh \& Shannon, 2005). In the initial process, the authors avoided using preconceived themes (Kondracki \& Wellman, 2002). Once data were collected and translated into English, a content analysis of the news stories was carried out to assign the news content to each theme that was identified in the interview coding. The same coders (i.e., the first and second authors) completed the coding and theme assignment tasks. The initial inter-coder reliability level was .90 , and afterwards, the coders further discuss the remaining differences until agreements were secured.

\section{Findings}

The current study identified four main themes and eight associated subthemes based on both the interview and media content analysis. These main and subthemes include (1) performance (on-field success, competition level), (2) personal/private (off-field characteristics, impression management), (3) business/marketing (athlete promotion, merchandized products), and (4) contextual factor (sport nature, proximity). The summaries of the themes and sub-themes are depicted in Table 2. In the following section, the authors further describe what the athlete and fans mentioned in terms of each theme, and how the media paid attention to each theme in a parallel fashion. 

Table 2 - Results

\begin{tabular}{|c|c|c|c|c|c|}
\hline $\begin{array}{l}\text { Construct } \\
\text { Themes }\end{array}$ & $\begin{array}{c}\text { Athlete } \\
\text { (1) }\end{array}$ & $\begin{array}{c}\text { Fans } \\
(2)\end{array}$ & $\begin{array}{l}\text { (In)consistency } \\
\text { between (1) \& } \\
\text { (2) }\end{array}$ & Descriptors of identified inconsistencies & $\begin{array}{c}\text { Media } \\
\text { attention }\end{array}$ \\
\hline \multicolumn{6}{|l|}{ Performance } \\
\hline - $\quad$ On-field success & $\mathrm{X}$ & $\mathrm{X}$ & Consistent & & $\mathrm{X}$ \\
\hline - Competition level & $\mathrm{X}$ & $\mathrm{X}$ & Consistent & & $\mathrm{X}$ \\
\hline \multicolumn{6}{|l|}{ Personal/Private } \\
\hline $\begin{array}{cc}\text { - } & \begin{array}{c}\text { Off-field } \\
\text { characteristics }\end{array} \\
\end{array}$ & $\mathrm{X}$ & $\mathrm{X}$ & Consistent & & $\mathrm{X}$ \\
\hline $\begin{array}{r}\text { - } \\
\text { Impression } \\
\text { management }\end{array}$ & $\mathrm{X}$ & $\mathrm{X}$ & Inconsistent & $\begin{array}{l}\text { Athlete - Impression is managed to respond to the } \\
\text { expectations of audience., which may sometimes make } \\
\text { athletes unreal. } \\
\text { Fans - Fans want to see the genuine aspects of athletes. }\end{array}$ & N/A \\
\hline \multicolumn{6}{|l|}{ Business/Marketing } \\
\hline $\begin{array}{c}\text { Athlete } \\
\text { promotion }\end{array}$ & $\mathrm{X}$ & $\mathrm{X}$ & Inconsistent & $\begin{array}{l}\text { Athlete -Financial stability is needed to focus on } \\
\text { performance. } \\
\text { Fans - Too much commercial involvement is not } \\
\text { accepted. }\end{array}$ & N/A \\
\hline $\begin{array}{l}\text { - } \quad \text { Merchandised } \\
\text { products }\end{array}$ & $\mathrm{X}$ & $\mathrm{X}$ & Inconsistent & $\begin{array}{l}\text { Athlete - Not sure about own branded products. } \\
\text { Fans - Okay to launch them. }\end{array}$ & N/A \\
\hline \multicolumn{6}{|l|}{ Contextual factor } \\
\hline - $\quad$ Sport nature & $\mathrm{X}$ & $\mathrm{X}$ & Consistent & & N/A \\
\hline - $\quad$ Proximity & N/A & $\mathrm{X}$ & Inconsistent & $\begin{array}{l}\text { Athlete - Athlete does not think about the fans who } \\
\text { have commonalities like distance, hometown, etc. } \\
\text { Fans - Fans aware and recognize athlete brands is } \\
\text { those athletes are close in distance, time, etc. }\end{array}$ & N/A \\
\hline
\end{tabular}

Source: Authors.

\section{(c) $)$ EY-NC-SA}

PODIUM Sport, Leisure and Tourism Review | São Paulo | v. 9 | Ed. Esp. | p. 70-96 | set./dez. 2020 
Hasaan, A., Javani, V., Fisner, M., \& Sato, S. (2020, set./dez.). Athlete branding in less popular sport: a triadic

Performance as a necessary factor for athlete branding

Performance is often considered as an attribute of strong sport brands and fan followership (Arai et al. 2013). Consistent performance is a major contributor at athlete brand maturity stage, and it can consist of multiple constructs such as achievements, style of play and skills (Hasaan, Biscaia, \& Ross, 2019).

On-field success. As an athlete representing a sport, demonstrating sporting success is necessary for its existence. There is an important relationship between sports branding and athlete's success as only winners, can be called a top athlete. In terms of this subtheme, Taha mentioned:

Sporting success is essential for athletes. Moreover, this success must be a top-level success such as World Cup, Olympics etc. Sporting success bought a recognition for you. Winners enjoy higher brand value. When an athlete becomes an Olympic champion (international level success), you become an international brand.

Fans mentioned that sporting success is not sufficient unless it is consistent. The consistent sporting success helps cement an athlete as a real brand.

The international achievements of Taha Akgül are very important. However, the important thing is that these achievements must continue steadily [F2].

For example, Lebron James is favorite of many basketball fans because of his consistent success in the NBA [F4].

The media covered the athlete's on-field success extensively. Interestingly, most news stories about the athlete were related to this sub-theme, and somewhat ignored domestic sporting success.

Taha Akgül won the gold medal in the men's freestyle at the European Wrestling Championship in the Dagestan Autonomous Republic of Russian Federation [media].

Competition level. Another aspect related to performance is the importance of the competition level. The big achievement at an internationally recognized competition, which can boost the popularity of the athletes. Although great performance sets a platform for future references, athletes will remain at an ordinary level unless they win something extraordinary. Taha explained: 
Hasaan, A., Javani, V., Fisner, M., \& Sato, S. (2020, set./dez.). Athlete branding in less popular sport: a triadic

The scope of competition defines scope of fans. For example, very few people do appreciate winning a Turkish championship. Only the wrestling community can appreciate you with a Turkish championship. However, when you have won an international competition whole country is talking about you as when you raise the national flag, people become proud of you. They start following you after that. Therefore, an athlete must succeed in international competitions.

Fans of the study acknowledged that it is some of Taha's success that pulled their attention towards him. As a sports athlete earns bigger achievements, more people are attracted toward the athlete. Local championship winners can attract locals while international championship winners can attract people all around the world. Fans mentioned that:

He became my favorite wrestler after the 2015 World Championship in the United States [F2].

I liked him but actually started following him when he became the European

Champion. His international success helped him to gain lots of popularity [F5].

The media also paid attention to the athlete being recognized by the international organization. Again, most news stories tend to ignore domestic achievement of the athlete.

The World Wrestling Association (UWW) has announced the list of the "best wrestlers in the world", which is traditionally published every year. National wrestlers Taha Akgül and Selçuk Çebi took first place in their categories [media].

\section{Athletes' personal/private life as a source of branding}

Past studies have identified that only on-field success is not enough to establish a top athlete brand (Lobpries, Bennett, \& Brison, 2018). Off-field attributes are also influential to establish a long lasting loyalty (Hasaan et al. 2018). Also, impression management, efforts to manage one's image (Bolino, Kacmar, Turnley, \& Gilstrap, 2008), is considered as a useful tool in the process of athlete brand development (Agyemang \& Williams, 2013; Hasaan et al. 2019).

Off-field characteristics. There are very few athletes in the history of the sport who become legends and icons. According to participants of the study, it is their off-field character that distinguish them from other athletes. Participants of the study also expressed that athlete's off- 
field character and personality are among top factors that make an athlete a popular brand. Taha expressed that:

The character makes the man a legend. The sporting success is okay, the championship is fine. But those make you the champion of sporting fields only. You are forgotten if you do not demonstrate the good character. Your attitude needs to be positive and your life should be clean because people are looking at you outside of the fields too.

In the context of the athlete's off-field characteristics, fans highlighted the importance of athletes' off-field attitude and behavior. For instance:

Athletes' off-field attitude should leave a positive impact on the community. They should be socially responsible and serve as a role model in the community [F4].

Athletes should set moral standards, follow the social norms and values, and demonstrate a role-model type behavior for young people [F6].

Media also covers athletes' attitude and behavior that are socially accepted although they may not care about or may not be able to detect the genuineness of the athletes. For example, media represented that:

Champion wrestlers Taha Akgül and Riza Kayaalp met with 11-year-old wrestler Melih Büyükyıldız to appreciate him who broke into tears after defeated by the opponent at Greco-Roman during Wrestling Championship held in Zonguldak, Turkey [media]

Impression management. This sub-theme is closely associated with off-field characteristics. Some athletes innately have favorable off-field characteristics and demonstrate positive attitude to the public. The important idea is that even if athletes who are not accustomed to demonstrate such positive attitudes to the community should be cognizant of the importance in managing impressions. Also, impression management is helpful when an athlete committed a mistake (Agyemang, 2011; Sato, Ko, Park, \& Tao, 2015). In this context, Taha mentioned that:

Some athletes can certainly do impression management. I mean, they may pretend, they may be unnatural, and they may be fake. They may show a completely different version of themselves to the media and people. But the fact is that they try to portray themselves to respond to fans' wishes and expectations. 
Being real is an important factor for building human relationships. But athletes apparently feel the need to demonstrate off-field characteristics that can be widely accepted in the society. Although it can be beneficial to develop favorable brands, it is apparent that fans think differently:

Athletes can sometimes be faking. They may be doing this to create a better image but it is not acceptable [F5].

Athletes should have the courage to present their true self. They have realized that they cannot portray a fake version to us [F9].

Closely related to the above statements, setting the bar high by demonstrating rolemodel type attitude and behavior may backfire when negative incidents such as transgressions occur. One of fans mentioned that:

When an athlete that I thought was a good guy is showing very negative attitude, it annoys the supporters. I kind of felt ashamed that I rooted for an athlete who actually had negativities in his heart [F10].

It is certainly worth noting that there are some inconsistencies in terms of impression management between the athlete and fans. The inconsistency between the athlete and fans was primarily related to whether athletes manage their genuine images or not.

\section{Business and marketing activities to boost athlete branding}

Effective marketing strategies create favorable brand associations and reinforce existing positive brand associations (Arai et al. 2014). Promotional activities are important to increase awareness and favorability of associations between athletes and fans (Hasaan et al. 2019). Based on the observations of the current study, we identified that there were both consistencies and inconsistencies between athletes and fans in terms of commercialization of athletes. It is important to understand such consistencies as it can impact brand development of athletes in less popular sport. 
Athlete promotion. Athletes especially in less popular sport need more marketing campaigns to survive both on and off the fields. In many countries, athletes in less popular sport receive significantly less financial support for their performance development just because the support for popular sport is usually prioritized. For instance, Taha mentioned that:

I think athletes should marketize themselves to become successful. It will be helpful to hire professional staff or buy necessary equipment and so forth. Endorsement offered a significant income to athletes. Other business activities also matter a lot for some athletes. But fans often doubt athletes' commitment to sport if the player get involved in commercial activities too much.

However, there is difference between the athlete and fans. Some participants expressed their oppositions toward commercializing athletes although they were supportive in terms of endorsement contracts. For instance:

I think athletes should not focus on making money. It's more appropriate for athletes to stay in the sports field and focus on the sport [F4].

I guess the balance is very important. Athletes should not prioritize making money over sport. [F5].

If I see Taha Akgül in a TV or magazine ad, I prefer the product he advertises [F6].

Merchandised products. Launching a merchandised product is different from endorsing products of companies. Many athletes who have strong brand values have successfully launched their name brands in various product lines. This can happen before developing strong athlete brands these days. Nevertheless, it is not clear when to launch their own name brands, and it can attract criticism from fans who unfavorably perceive athletes' commercial involvement. Taha mentioned that:

Maybe one day, but not at this moment. I personally do not have such a commercial talent. More importantly, I do not think it is the right time now.

Participants of the study positively see the idea of launching Taha's name brand. As they mentioned that if Taha will launch his line of products, they would love to buy them. Fans acknowledged that their positive attitude toward Taha's name brands is based on their liking 
toward the athletes. However, it is worth noting that they did not react negatively to the commercial activity in terms of launching own name brand products.

If Taha Akgül comes out of a shoe brand or another product like a tracksuit, I prefer to buy. But I guess it's just because I like him. I am not sure if I am willing to buy such products if I was not a fan of this sport. [F7]

\section{Contextual factors associated with athlete branding}

Contextual factors refer to the information that may be indirectly associated with the link between athletes and their branding (Sato, Ko, Kaplanidou, \& Connaughton, 2016). For example, Hasaan et al. (2018) mentioned that the popularity of the sport can influence (dis)liking of a particular athlete. Whether the focal sport is popular or not is not a dispositional (i.e., internal) attribute of the athlete, but it can impact how consumers perceive the athlete. Similarly, the types of sport (i.e., team vs. individual) can also impact how consumers perceive athletes (Nicholls, Polman, Levy, \& Backhouse, 2009). The concept of proximity identified in the current study is also worth noting. The previous literature suggested that proximity can serve as a source of the identity connection between fans and sport teams (Lock \& Funk, 2016). The current study yielded a similar finding in the athlete branding context.

Sport nature. The popularity and type of sport can impact athlete branding. A footballer in Brazil, for example, can become the talk of the town. Athletes who compete less popular sport have to work hard to become popular. The nature of sport can be a driving force of athlete branding. In terms of this subtheme, Taha stated that:

Your brand value will grow more easily if your sport is popular. In our country, football is obviously more popular than wrestling. I think I would have been much more known and appreciated if I achieved just about a half (of what he achieved in wrestling) in Football...... For athletes in less popular sport, building brands can be more controllable for individual sport because (in team sport) your brand value is influenced by not only what you do but also the successes of teams and teammates. 
All of the study participants acknowledged that sport type can play an integral role in athlete. For example,

If you ask me about a cricketer, I have no idea. But if you ask about a cricketer to any Indian or Pakistani, they will probably be able to describe the athlete. [F4]

In team sports, even a superior talent in your team can help grow your brand, but your individual achievement is absolutely necessary in individual sport. It's more demanding for athletes in individual sport but it can be more rewarding as well. [F2]

Proximity. Participants of the study mentioned that proximity might increase an athlete's following. The fans discussed that proximity helped to create a relation. The proximity that is closeness in space, time, or relationship provides an athlete with the edge over non-related athletes. For instance,

I am from Sivas (Taha's hometown). I started following him since his emergence at a national level as he (Taha) and me belong to the same city. [F7]

He (Taha) is my city fellow, my country fellow, and my religious fellow

So we have a lot commonalities. I guess some sort of relations always pays you because Taha is probably less popular amongst people who own different attributes such as nonSivas people and non-Turks. [F9]

The concept of proximity was not mentioned by the athlete. It could be important for athletes in less popular sport to start focusing on fans who are closer to themselves in terms of space, time, and relationship, rather than developing their brands might be perceived favorably by people who are in the other side of the world.

\section{Discussion}

The current study aimed to explore the effectiveness of personal branding development strategies for athletes who competes in the less popular sport. For that purpose, this study considered Taha Akgül as a case study and investigated perceptions and expectations of athlete branding between athletes and fans. Secondly, the study also examined how media attention is allocated based on media content analysis. Although previous studies have discussed athletes branding, there is a lack of theoretical understanding of the three prospective in a single study, that is, athlete perspective; fans perspective; and media perspective. The current study identified 
four main themes and eight associated subthemes. These main and subthemes include (1) performance (on-field success, competition level), (2) personal/private (off-field characteristics, impression management), (3) business/marketing (athlete promotion, merchandized products), and (4) contextual factor (sport nature, proximity).

According to the findings, performance of an athlete is a major contributor to develop an athlete brand in less popular sport. That is in line with past literature as according to Arai et al. (2013), one of the major factors to a successful athlete branding is athlete performance. Past studies have identified the importance of on-field success for an athlete as it is almost impossible to establish an athlete's brand without on-field success (Chung, Brown, \& Willett, 2019; Kristiansen \& Williams, 2015). Arai et al. (2014) mentioned that an athlete's performance is consist of all sports performance related features. In the case of Taha Akgül, the identified components of performance are the consistency of success and level of achievements. As reliable success at higher level endorsed athletes' strengths and uniqueness to a targeted audience (i.e. fans). For instance, long-term success can influence an athlete brand by steering him/her to achieve star status (Ross, 2006). Also, past studies have mentioned that not only a consistent success but a quality performance (i.e., level of achievements) also aided in athletes branding efforts (Grant, Heere, \& Dickson, 2011; Hasaan et al. 2018). That is why to establish a successful brand for an athlete who represented a less popular sport, on-field success and achievements at highest tournaments and competitions (i.e., competition level) are indispensable.

The results of the study also identified that personal/ private factors can also help in the athlete's quest for building brands. Previous literature discussed that on-field success only is not a sufficient force to create an athlete brand (Lobpries et al. 2018). Indeed, it also requires favorable off-field character and personality (Hasaan et al. 2018; Lee \& Kwak, 2017; Yu, 2005). In the current study, both the athlete and fans emphasized the importance of off-field characteristics, which is consistent with the findings in the previous literature. Also, the current study found the importance of impression management in building athlete brands. Some already well-known athletes such as Roger Federer (Tennis), Serena Williams (Tennis), and Cristiano Ronaldo (Football) pro-actively used various media channels to manage their impression among fans (Agyemang, Williams, \& Kim, 2015; Geurin, 2017). Athletes in less popular sport also need to implement impression management strategies because the negative information regarding an athlete's personal life could harm an athlete's brand and public image (Hassan et 
al. 2018; Sato et al. 2015). However, it is important to note that fans in the current study were skeptical about impression management as fans want to know genuine aspects of the athletes. Although it is difficult to generalize, the authors speculate that such needs could be stronger among fans rooting for athletes in less popular sport. Athletes in less popular sport, therefore, may want to focus more on portraying true-themselves to their fans as that is what fans expect.

The third theme of athlete branding is about marketing/business factors. Carter (2010) claimed that human brands can be defined as individuals who are subject to marketing efforts. Indeed, it has been extremely common to see athletes and business managers work together to build brands and maximize financial gains from it. In fact, the stable financial circumstances are essential for athletes to improve on-field performances (Andreff, 2006). Many scholars have agreed with the idea of actively promoting athletes (Biscaia et al. 2013; Choi \& Rifon, 2007; Fişne, Gül, \& Soygüden, 2017; Till, 2001). The current study, however, identified challenges in terms of business-oriented promotional efforts as fans dislike athlete's commercial activities. During the interview, Taha expressed dilemmas regarding earning money or fans support. However, the current study also found that fans' dislike toward athletes' commercial involvement was based on an idea that athletes may become less determined to sporting success. Above all, it could be concluded that athletes in less popular sport can still engage promotional activities while demonstrating consistent sporting successes must be prioritized. With regard to another subtheme, Taha and his fans were also mentioned that athletes can launch their own brand merchandized products. Although Taha was not sure about the idea, fans are willing to buy Taha's name brand products to support his sport career. Incorporating the above statement made by fans, the authors speculate that fans positively consider athletes' commercial activities if the purpose of doing them is to bring positive impact on on-field performance.

The contextual factors refer to the information that may be indirectly associated with the link between athletes and their branding (Sato, Ko, Kaplanidou, \& Connaughton, 2016). During the interview, participants of the study described that the nature of sport is not a part of athletes, but it can influence the branding process. As a baseline, participants thought that athlete branding in popular sport is less challenging comparing to less popular sport. Interestingly, participants also mentioned that branding athletes in team sport is less challenging than individual sport athletes, but performance achievements of individual athletes directly impact their branding. Hence, it could be reasoned that athletes in less popular sport can have more control over their branding process if they can demonstrate outstanding on-field 
performance in individual sport. A few studies have discussed that teams' success history help to strengthen the positive perceptions of athletes in the team (Hasaan et al. 2018; Kerr \& Emery, 2011). It is because the successful groups serve as the information cue, which makes people think that the associated members of the group are also successful (Sato et al. 2016). Nevertheless, such positive influences from the group are divided by its members - the amount of positive influence each member can receive may be minimal especially when the group is large (Fink, Parker, Brett, \& Higgins, 2009). In this vein, solo sport athletes - while their onfield success entirely depends on themselves - can receive the full credits from their success. The current study provides useful information with practitioners who build and manage athlete branding in less popular sport. Specifically, the nature and type of sport have different characteristics in terms of athlete branding. Finally, participants mentioned that the proximity to athletes is a potential driving force to build strong athlete brands in less popular sport. This contention is consistent with previous literature in the team sport context, indicating that close relationship with teams (e.g., distance) can lead to attachment and loyalty (Havard, Reams, \& Gray, 2013; Stever, 2011). It is important to note that the athlete in the current study did not recognize the importance of this factor. The authors speculate that the relationship between athletes in less popular sport and fans are closer simply because consumers with low involvement may not follow less popular athletes and sport. Considering the findings of the current study, it could be practical for athletes in less popular sport to focus highly on existing close fans first.

Overall, the study highlighted the gap between multiple stakeholders involving the athlete, fans, and media. The athlete branding managers can consider that both on-field and offfield success are the important factors to build strong brands. Also, athletes should emphasize the reason to be involved in commercial activities. Fans do not exhibit negative attitude toward athletes involving with commercial activities if they use the financial gains for their expert domain (i.e., on-field performance). Lastly, athletes and their managers should understand that internationally succeeded athletes receive only limited media exposure if their sport is less popular in the society. Furthermore, the media content analysis conducted in the current study showed that although media paid only handful of attention to the athlete's involvement in a philanthropic activity, the majority of the media attention was allocated to on-field performance only. Hence, even for internationally recognized athletes, building athlete brands in less popular sport highly relies on their on-field performance. 


\section{Limitations and future research directions}

The study offer a number of possibilities for future research. Although this study is based on exploratory qualitative research design, which is best suited when little is known about a topic and the researcher needs to understand more from the participant's perspective (Merriam, 2009). However, future studies could employ quantitative methods in order to provide further support for these findings with a larger sample of sports fans. Also, the current study focused a wrestler from Turkey. There is long list of sports that are unpopular in certain countries/culture. In this sense, a sample of fans and athlete from different sport, countries and cultures could bring more detailed effects. As every culture owned its norms and traits, focusing less popular athletes from other sports, countries and cultures could elaborate the topic further. Additionally, more diversity could be achieved via focusing on specific gender (i.e., female athlete or female fans).

As mentioned in the study there is lack of studies that clearly posit an understanding regarding athlete of a team sport vs athlete of an individual sport in context of athlete branding. Past studies have highlighted that athletes of solo sport and team sport faced different patterns of branding (Hasaan et al. 2018; Fink et al. 2009), however, no study addressed the topic precisely. Therefore, future studies could use this direction to fill the gap in the literature.

The current study opted to evaluate one website for content analysis. Although, it is the most popular website of the country but future studies could use other sources of information as well. For instance in a digital world, information from mass media as well as social networks can also verify the power of social networks in promoting less popular athletes and sports. In future work, the mixing of this information will helpful for both the literature as well as managers.

The current study highlighted the difference between thoughts of athletes and fans. For instance, 'impression management' and 'athlete's marketing efforts' presented a diverse perspective of both. In this scenario, more detailed study to address the viewpoint of two could help the managers and athletes to address the brand customer more effectively.

\section{References}

Aaker, D. (1991). Managing Brand Equity: Capitalizing on the Value of a Brand Name. New York: Free press. 
Agyemang, K. (2011). Athlete brand revitalisation after a transgression. Journal of Sponsorship, 4, 137-144.

Agyemang, K. J. A., \& Williams, A. S. (2013). Creating revenue via Organisational "Brandpression" Management (OBpM): A marriage of brand management and impression management in professional sport. International Journal of Revenue Management, 7(2), $171-181$.

Agyemang, K. J. A., Williams, A. S., \& Kim, D. (2015). “Scandalous!”: Reputation, impression management, and employee assistance programs (EAPs) in the NBA. Sport Management Review, 18(4), 609-617.

Ali-Choudhury, R., Bennett, R., \& Savani, S. (2009). University marketing directors' views on the components of a university brand. International Review on Public and Nonprofit Marketing, 6(1), 11.

Andreff, W. (2006). Sport in Developing Countries. In W. Andreff \& S. Szymanski (Eds.), Handbook on the Economics of Sport (pp. 308-315). Cheltenham: Edward Elgar.

Arai, A., Ko, Y. J., \& Kaplanidou, K. (2013). Athlete brand image: scale development and model test. European Sport Management Quarterly, 13(4), 383-403.

Arai, A., Ko, Y. J., \& Ross, S. (2014). Branding athletes: Exploration and conceptualization of athlete brand image. Sport Management Review, 17(2), 97-106.

Augestad, P., Bergsgard, N. A., \& Hansen, A. Ø. (2006). The institutionalization of an elite sport organization in Norway: The case of "Olympiatoppen”. Sociology of Sport Journal, 23, 293-313.

Berg, B. (2000). Qualitative Research Methods for the Social Sciences. Needham, MA: Allyn \& Bacon

Biscaia, R., Correia, A., Ross, S., Rosado, A., \& Maroco, J. (2013). Spectator-Based Brand Equity in Professional Soccer. Sport Marketing Quarterly, 22(1), 20-32.

Bolino, M., Kacmar, M., Turnley, H., \& Gilstrap, B. (2008). A multi-level review of impression management motives and behaviors. Journal of Management, 34(6), 1080 1109.

Browne, K. (2005). Snowball sampling: using social networks to research non-heterosexual women. International journal of social research methodology, 8(1), 47-60.

Campbell, J., Quincy, C., Osserman, J., \& Pedersen, O. (2013). Coding In-depth Semistructured Interviews: Problems of Unitization and Intercoder Reliability and Agreement. Sociological Methods \& Research, 42(3), 294-320.

Carter, D. M. (2010). Money Games: Profiting From the Convergence of Sports and Entertainment. Stanford, CA: Stanford University Press. 
Chadwick, S., \& Burton, N. (2008). From Beckham to Ronaldo -- Assessing the nature of football player brands. Journal of Sponsorship, 1(4), 307-317.

Chen, C.-P. (2013). Exploring Personal Branding on YouTube. Journal of Internet Commerce, 12(4), 332-347.

Chen, C. Y., Lin, Y. H., \& Claussen, C. L. (2012). Celebrity endorsement for sporting events using classical conditioning. International Journal of Sports Marketing and Sponsorship, 13(3), 46-56.

Choi, S., \& Rifon, N. (2007). Who Is the Celebrity in Advertising? Understanding Dimensions of Celebrity Images. The Journal of Popular Culture, 40(2), 304-324.

Chung, K. S., Brown, C., \& Willett, J. (2019). Korean MLB players: the effects of motives and identification on fan loyalty. Sport, Business and Management: An International Journal. 9(3):239-254

Corbin, J., \& Strauss, A. (2008). Basics Of Qualitative Research: Techniques And Procedures For Developing Grounded Theory (3rd ed.). London: Sage.

Cortsen, K. (2013). Annika Sörenstam - a hybrid personal sports brand. Sport, Business and Management: An International Journal, 3(1), 37-62.

Creswell, J.W. (2003). Research design: Qualitative, quantitative, and mixed methods approaches. Thousand Oaks, CA: SAGE Publications.

Delisle, M.-P., \& Parmentier, M.-A. (2016). Navigating Person-Branding in the Fashion Blogosphere. Journal of Global Fashion Marketing, 7(3), 211-224.

Dickson, G., \& Santos, M. C. M. (2016). Globalisation and professional sport. In N. Schulenkorf \& S. Frawley (Eds.), Critical Issues in Global Sport Management (pp. 115128). Oxon: Routledge.

Fink, J. S., Cunningham, G. B., \& Kensicki, L. J. (2004). Using athletes as endorsers to sell women's sport: Attractiveness vs. expertise. Journal of Sport management, 18(4), 350-367.

Fink, J. S., Parker, H. M., Brett, M., \& Higgins, J. (2009). Off-field behavior of athletes and team identification: Using social identity theory and balance theory to explain fan reactions. Journal of Sport Management, 23, 142-155.

Fişne, M., Gül, M., \& Soygüden, A. (2017). Assessment of Expectations and Perceptions of Sport Business Customers for Service Quality: A Study of Sport Business Sector in Sivas, Turkey. Pamukkale Journal of Sport Sciences, 8(1), 1-13.

Franck, E., \& Nüesch, S. (2012). Talent and/or Popularity: What Does It Take To Be a Superstar? Economic Inquiry, 50(1), 202-216.

Geurin, A. N. (2017). Elite female athletes' perceptions of new media use relating to their 
careers: A qualitative analysis. Journal of Sport Management, 31(4), 345-359.

Grant, N., Heere, B., \& Dickson, G. (2011). New Sport Teams and the Development of Brand Community. European Sport Management Quarterly, 11(1), 35-54.

Harris, M. (2009). Message in a Bottle: University Advertising During Bowl Games. Innovative Higher Education, 33(5), 285-296.

Hasaan, A., Biscaia, R., \& Ross, S. (2019). Understanding athlete brand life cycle. Sport in Society. DOI: 10.1080/17430437.2019.1624722.

Hasaan, A., Kerem, K., Biscaia, R., \& Agyemang, K. J. A. (2018). A conceptual framework to understand the creation of athlete brand and its implications. Int. J. Sport Management and Marketing, 18(3), 169-198.

Havard, C. T., Reams, L., \& Gray, D. P. (2013). Perceptions of highly identified fans regarding rival teams in US intercollegiate football and men's basketball. International Journal of Sport Management and Marketing, 14(1-4), 116-132.

Hodge, C., \& Walker, M. (2015). Personal branding: a perspective from the professional athlete-level-of-analysis. International Journal of Sport Management and Marketing, $16(1 / 2), 112-131$.

Hsieh, H., \& Shannon, S. (2005). Three Approaches to Qualitative Content Analysis. Qual Itative Health Research, 15(9), 1277-1288.

Jonker, L., Elferink-Gemser, M. T., \& Visscher, C. (2009). Talented athletes and academic achievements: a comparison over 14 years. High Ability Studies, 20(1), 55-64.

Keller, K. L. (1993). Conceptualizing, Measuring, Managing Customer-Based Brand Equity. Journal of Marketing, 57(1), 1-22.

Kerr, A. K., \& Emery, P. R. (2011). Foreign fandom and the Liverpool FC: a cyber-mediated romance. Soccer \& Society, 12(6), 880-896.

Kerr, A. K., \& Gladden, J. M. (2008). Extending the understanding of professional team brand equity to the global marketplace. International Journal of Sport Management and Marketing, 3(1-2), 58-77.

Kim, Y. J., \& Na, J. H. (2007). Effects of celebrity athlete endorsement on attitude towards the product: the role of credibility, attractiveness and the concept of congruence. International Journal of Sports Marketing and Sponsorship, 8(4), 23-33.

Knight, J. L., \& Giuliano, T. A. (2001). He's a Laker; she's a "looker": The consequences of gender-stereotypical portrayals of male and female athletes by the print media. Sex roles, 45(3-4), 217-229.

Kondracki, N., \& Wellman, N. (2002). Content Analysis: Review of Methods and their 
Applications in Nutrition Education. Journal of Nutrition Education and Behavior, 34, 224-230.

Kristiansen, E., \& Williams, A. S. (2015). Communicating the athlete as a brand: An examination of LPGA star Suzann Pettersen. International Journal of Sport Communication, 8(3), 371-388.

Kunkel, T., Hill, B., \& Funk, D. C. (2013). Brand Architecture , Drivers of Consumer Involvement, and Brand Loyalty With Professional Sport Leagues and Teams. Journal of Sport Management, 22(3), 177-192.

Lee, J. S., \& Kwak, D. H. (2017). Can winning take care of everything? A longitudinal assessment of post-transgression actions on repairing trust in an athlete endorser. Sport Management Review, 20(3), 261-272.

Lobpries, J., Bennett, G., \& Brison, N. (2018). How I Perform is Not Enough: Exploring Branding Barriers Faced by Elite Female Athletes. Sport Marketing Quarterly, 27(1), 5-17.

Lock, D. J., \& Funk, D. C. (2016). The multiple in-group identity framework. Sport Management Review, 19, 85-96.

Macnamara, J. (2011). Media content analysis: Its uses; benefits and best practice methodology. Asia Pacific Public Relations Journal, 6(1), 1-34.

Marshall, M. (1996). Sampling for Qualitative Research. Familiy Practice, 13, 522-525.

Marshall, C., \& Rossman, G. B. (1995). Designing Qualitative Research (2nd ed.). Thousand Oaks: Sage.

McTavish, D., \& Loether, H. (2015). Social Research: An Evolving Process. Noida: Pearson Education.

Merriam, S. B. (2009). Qualitative research: A guide to design and implementation. San Francisco, CA: Jossey-Bass.

Mike, C. R. (2013, July 12). Could This Be Wrestling's Next Great Heavyweight? BodyElbow. Retrieved from https://www.bloodyelbow.com/2013/7/12/4516590/could-thisbe-wrestlings-next-great-heavyweight

Montoya, P., \& Vandehey, T. (2002). The Personal Branding Phenomenon. Nashville, TN: Personal Branding Press.

Newbold, C., Boyd-Barrett, O., \& Van Den Bulck, H. (2002). The Media Book. Londin: Arnold.

Nicholls, A., Polman, R., Levy, A., \& Backhouse, S. (2009). Mental toughness in sport: Achievement level, gender, age, experience, and sport type differences. Personality and Individual Differences, 47(1), 73-75. 
Okumus, F., Altinay, L., \& Roper, A. (2007). Gaining Access for Research: Reflections from Experience. Annals of Tourism Research, 34(1), 7-26.

Parmentier, M.-A., \& Fischer, E. (2012). How athletes build their brands. International Journal of Sport Management and Marketing, 11(1/2), 106-124.

Patton, M. Q. (2002). Qualitative research and evaluation methods. Newbury Park, CA: Sage.

Quliyev, T. (2018, September 7). Taha Akgül: We will achieve to wave both Turkish and Azerbaijani flags at world championship. Report News Agency. Retrieved from https://report.az/en/individual/taha-akgul-we-will-achieve-to-wave-both-turkish-andazerbaijani-flags-at-world-championship/

Rampersad, H. K. (2009). Authentic Personal Branding: A New Blueprint for Building and Aligning a Powerful Leadership Brand. Charlotte: Information Age Publishing.

Rein, I. J., Kotler, P., \& Shields, B. (2006). The elusive fan: Reinventing sports in a crowded marketplace. New York: McGraw-Hill.

Ross, S. (2006). A conceptual framework for understanding Spectator-Based Brand Equity. Journal of Sport Management, 20(1), 22-38.

Sato, S., Ko, Y. J., Chang, Y., \& Kay, M. (2019). How does the negative impact of an athlete's reputational crisis spill over to endorsed and competing brands? The moderating effects of consumer knowledge. Communication \& Sport, 7(3), 385-409.

Sato, S., Ko, Y. J., Kaplanidou, K. K., \& Connaughton, D. P. (2016). Consumers' comparative evaluative judgment of athlete endorsers. Journal of Sport Management, $30(5), 553-565$.

Sato, S., Ko, Y. J., Park, C., \& Tao, W. (2015). Athlete reputational crisis and consumer evaluation. European Sport Management Quarterly, 15(4), 434-453.

Stever, G. (2011). Fan Behavior and Lifespan Development Theory: Explaining Para-social and Social Attachment to Celebrities. Journal of Adult Devvelopment, 18(1), 1-7.

Thomson, M. (2006). Human Brands: Investigating Antecedents to Consumers' Strong Attachments to Celebrities. Journal of Marketing, 70(3), 104-119.

Till, B. D. (2001). Managing Athlete Endorser Image: The Effect of Endorsed Product. Sport Marketing Quarterly, 10(1), 35-42.

Till, B. D., \& Busler, M. (2000). The match-up hypothesis: Physical attractiveness, expertise, and the role of fit on brand attitude, purchase intent and brand beliefs. Journal of Advertising, 29(3), 1-13.

Underwood, R. (2003). The communicative power of product packaging: creating brand 
identity via lived and mediated experience. Journal of Marketing Theory and Practice, $11(1), 62-76$.

Walsh, P., \& Williams, A. (2017). To extend or not extend a human brand: An analysis of perceived fit and attitudes toward athlete brand extensions. Journal of Sport Management, $31(1), 44-60$.

Watkins, B. A., \& Gonzenbach, W. J. (2013). Assessing university brand personality through logos: an analysis of the use of academics and athletics in university branding. Journal of Marketing for Higher Education, 23(1), 15-33.

Wylleman, P., \& Reints, A. (2010). A Lifespan Perspective on the Career of Talented and Elite Athletes: Perspectives on High-Intensity Sports. Scandinavian Journal of Medicine and Science in Sports, 20(s2), 88-94.

Yin, R. K. (2011). Qualitative Research from Start to Finish. New York: The Guilford Press.

Yu, C. (2005). Athlete endorsement in the international sports industry: a case study of David Beckham. International Journal of Sports Marketing \& Sponsorship, 6(3), 189-200. 